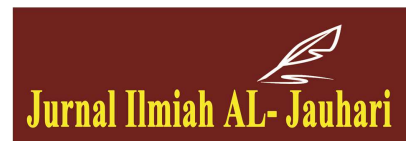

Jurnal Ilmiah ALo-Jauhari: Jurnal Studi Islam dan Interdisipliner

Volume 5 No 1, (April 2020): Halaman 99-120

ISSN (Print): 2541-3430, ISSN (Online): 2541-3449

Website: http://journal.iaingorontalo.ac.id/index.php/aj

\title{
Strategi Pengawas Guru Pendidikan Agama Islam dalam Meningkatkan Tata Kelola Kelas di Sekolah Dasar Negeri
}

\author{
Khadijah Towali, Said Subhan Posangi \\ (Kementerian Agama Kabupaten Pohuwato, \\ IAIN Sultan Amai Gorontalo) \\ izantowali@gmail.com, saidsubhan70@iaingorontalo.ac.id
}

\begin{abstract}
This study aims to evaluate the Implementation of Supervision of Islamic Religious Education Teachers in improving elementary school classroom management in Marisa District. The research method used is qualitative research, using data collection techniques through observation, interviews, and documentation. The results showed that: 1) The supervisory strategy carried out by all supervisors is to plan and prepare the supervisory apparatus before conducting supervision. The supervisory tools are collected in annual, semester and monthly programs. 2) To get maximum results in supervision, an appropriate approach is needed. The approach in supervision is called technique, both individual and group, each of which has advantages and disadvantages. 3) Overcoming obstacles by collaborating between supervisors and school principals is to set an example or good role model from the principal and senior teachers who are appointed as supervisors, as well as to provide guidance or overall improvement to the professional abilities of teachers by taking into account the accuracy of supervision techniques and principles supervision applied
\end{abstract}


Penelitian ini bertujuan mengevaluasi pelaksanaan pengawasan guru Pendidikan Agama Islam dalam meningkatkan tata kelola kelas Sekolah Dasar se-Kecamatan Marisa. Metode penelitian yang digunakan adalah penelitian kualitatif, dengan menggunakan teknik pengumpulan data melalui observasi, wawancara, dan dokumentasi.

Hasil penelitian menunjukkan bahwa: 1) Strategi kepengawasan yang dilakukan oleh semua pengawas adalah merencanakan dan menyiapkan perangkat kepengawasannya sebelum melakukan supervisi. Perangkat kepengawasan tersebut terhimpun dalam program tahunan, semester dan bulanan 2) Untuk mendapatkan hasil yang maksimal dalam supervisi, diperlukan suatu pendekatan yang tepat. Pendekatan dalam supervisi disebut teknik, baik yang bersifat individual maupun kelompok yang masing-masing memiliki kelebihan dan kekurangan. 3) Mengatasi hambatan dengan kerjasama antara pengawas dengan kepala sekolah adalah memberi contoh atau suri tauladan yang baik dari kepala sekolah maupun guru senior yang ditunjuk sebagai supervisor, serta melakukan pembinaan atau perbaikan secara menyeluruh terhadap kemampuan profesional guru dengan memperhatikan ketepatan teknik supervisi dan prinsip-prinsip supervisi yang diterapkan.

Kata Kunci: Strategi Pengawas , Guru PAI, Tata Kelola Kelas

\section{Pendahuluan}

Suasana sekolah merupakan modal penting bagi jernihnya pikiran untuk mengikuti pelajaran.Oleh karena itu dibutuhkan suatu keadaan yang menyenangkan demi meningkatkan motivasi peserta didik dalam mengikuti kegiatan pelajaran, untuk mengatasinya dibutuhkan manajemen kelas, yaitu penanganan yang baik agar dalam kegiatan belajar mengajar dapat berjalan dengan lancar dan tujuan yang telah ditetapkan dapat tercapai.

Kelas merupakan suatu tempat anak belajar untuk mendapatkan ilmu, berinteraksi dengan teman serta pembentukan pribadi yang baik.Kegiatan belajar peserta didik yang berada di sekolah diharapkan secara intens berjalan di kelas. Dalam lingkup kelas terdiri dari peserta didik yang dapat ditinjau dari cara belajar mereka, karakter peserta didik, hubungan sosial, kedisiplinan, dan tanggung jawab dalam proses belajar mengajar.

Salah satu pendekatan manajemen kelas yang baik ialah menyediakan kesempatan bagi peserta didik untuk sedikit demi sedikit 
mengurangi ketergantungannya kepada guru, sehingga mereka mampu membimbing kegiatannya sendiri.Sebagai manajer, guru hendaknya mampu memimpin kegiatan belajar yang efektif serta efisien dengan hasil optimal. ${ }^{1}$

Suatu sistem pendidikan dikatakan berkualitas jika proses pembelajarannya berlangsung secara menarik dan menantang sehingga peserta didik dapat belajar sebanyak mungkin melalui proses belajar yang berkelanjutan. Proses pendidikan yang berkualitas akan membuahkan hasil pendidikan yang berkualitas pula, dan dengan demikian akan makin meningkatkan kualitas kehidupan bangsa. ${ }^{2}$

Masalah pengelolaan kelas dapat dikelompokkan menjadi dua kategori, yaitu masalah individual dan masalah kelompok.Meskipun seringkali perbedaan antar kedua kelompok itu hanya merupakan perbedaan tekanan saja. Tindakan pengelolaan kelas seorang guru akan efektif apabila ia dapat mengidentifikasi dengan tepat hakekat masalah yang sedang dihadapi, sehingga pada gilirannya dapat memilih strategi penanggulangan yang tepat pula. ${ }^{3}$

Pengangkatan pengawas Guru PAI dari Pemkot/Pemkab hendaknya bukan lagi menampung usia pensiun atau karena mantan pejabat. Profesionalisme betul-betul menjadi pertimbangan dan yang tidak kalah pentingnya adalah tunjangannya. Ataukah, para bupati/walikota lupa akan pentingnya kehadiran seorang pengawas sekolah yang profesional sehingga masalah profesionalisme pengawas kurang mendapat perhatian. Misalnya, bagaimana bisa melaksanakan tugas untuk membina guru PAI kalau tidak pernah menjadi guru. Menjadi pengawas bukanlah memarahi guru, melainkan membina bahkan sebagai mitra kerja. Bila perlu, pengawas memberikan contoh cara pembelajaran materi tertentu jika guru mengalami kesulitan di kelas.

Berdasarkan paparan diatas, pengawas guru PAI dari Kemenag yang memang membidangi langsung kinerja guru PAI disetiap sekolah harus lebih maksimal karena kegiatan kepengawasan Guru menjadi salah satu penyebab tinggi rendahnya kinerja guru PAI terutama Pengawas pendidikan yang dikembangkan melalui sekolah sebagai sumber pembangunan moral Bangsa, memikul beban yang sangat berat. Kedudukan seorang pengawas merupakan juru kunci (key position) pendidikan harus menyadari bahwa masalah yang

\footnotetext{
${ }^{1}$ Djamarah, Syaiful Bahri dan Aswan Zain, Strategi Belajar Mengajar.(Jakarta: Rineka Cipta, 2002), h. 12

${ }^{2}$ Radno Harsanto, Pengelolaan Kelas yang Dinamis. (Yogyakarta : Kanisius, 2007), h. 105.

${ }^{3}$ Ahmad Rohani, Pengelolaan Pengajaran. (Jakarta. PT. Rineka Cipta, 2004), h. 124
} 
paling utama adalah bagaimana mempertumbuhkan personal dan professional Guru-guru yang di- awasinya sehingga kinerja guru pun meningkat.karena guru memang dituntut memiliki kinerja yang tinggi khususnya guru pendidikan agama islam untuk terus mengembangkan diri agar dapat mengikuti perkembangan yang cepat dalam bidang ilmu pengetahuan dan teknologi.Islam memberikan rambu-rambu bagi umatNya.

Penyebab rendahnya kualitas pendidikan di Indonesia ini bersifat kompleks hal ini dikarenakan tanggung jawab peningkatan mutu pendidikan itu bersifat kolektif baik lembaga pendidikan, tenaga pendidik, kepala sekolah dan pengawas sekolah bertanggung jawab atas maju dan mundurnya dunia pendidikan di Indonesia.Masingmasing dituntut memiliki komitmen menghasilkan kinerja yang bagus dan hasil yang membanggakan.

Berdasarkan survey awal terungkap bahwa pengawas Guru PAI angkatan Pemda yang ada di SD se Kecamatan Marisa diasumsikan masih kurang maksimal menjalankan tugasnya, hal ini disebabkan karena hanya berjumlah satu orang, akan tetapi juga pengawas tersebut bukanlah mantan guru melainkan mantan penjabat pemda. Sehingga pada perencanaan pengawasan, pelaksanaan pengawasan maupun pada penilaian pengawasan masih mengalami beberapa kendala.

Pengawas atau supervisor yang professional memiliki strategi untuk kemajuan pendidikan di Indonesia, begitupun pengawas Guru PAI di kecamatan Marisa tengah hendaknya memiliki strategi untuk meningkatkan mutu pendidikan melalui peningkatan kinerja gurunya khususnya guru PAI, dalam hal ini pengawas Guru PAI dan pengawas Guru PAI Kemenag harus saling bersinergi dalam mengembangkan pegawasan dalam guna meningkatkan tata kelola kelasUntuk itu penulis ingin membahas lebih lanjut bagaimana Strategi Pengawas Guru PAI dalam meningkatkan tata kelola kelas Sekolah Dasar seKecamatan Marisa.

\section{Kompetensi Pengawas Dalam Pengelolaan Kelas.}

Mengacu pada Surat Keputusan MENPAN pengawas sekolah di lingkungan Kementerian Agama khususnya direktorat jendral pembinaan kelembagaan agama Islam yang kemudian diberi istilah "Pengawas Pendidikan Agama Islam (PPAI)" sehingga muncul beberapa pengertian yang lebih spesifik tentang pengawas pendidikan agama Islam diantaranya ialah:

a. Menurut KEPMENPAN Nomor 118/1996 (Pasal 1 ayat 1), pengawas sekolah adalah pegawai negeri sipil yang diberi tugas, tanggung jawab dan wewenang secara penuh oleh pejabat yang

102 | Khadijah Towali 
berwewenang untuk melakukan pengawasan pendidikan di sekolah dengan melaksanakan penilaian dan pembinaan dari segi teknis pendidikan dan administrasi pada satuan pendidikan pra sekolah, sekolah dasar dan sekolah menengah.

b. Menurut KEPMENPAN Nomor 118/1996 (Pasal 3 ayat 1), pengawas sekolah adalah pejabat fungsional yang berkedudukan sebagai pelaksana teknis dalam melakukan pengawasan pendidikan terhadap sekolah tertentu yang ditunjuk. Berdasarkan peraturan KEPMENPAN tersebut pengawas sekolah merupakan Pegawai Negeri Sipil (PNS) yang tidak ada kualifikasi baik dari guru ataupun kepala sekolah.

c. Menurut PERMENDIKNAS No 12 Tahun 2007, pengawas sekolah adalah guru yang diangkat dan diberi tugas, tanggung jawab dan wewenang secara penuh oleh pejabat yang berwewenang untuk melakukan pengawasan pendidikan disekolah dengan melakukan penilaian dan pembinaan dari segi teknis dan administrasi pada satuan pendidikan pra sekolah, sekolah dasar dan sekolah menengah.

d. Menurut PERMENAG Nomor 2 Tahun 2012 (bab I Pasal 1 ayat 4), Pengawas Pendidikan Agama Islam (PPAI) yang disebut pengawas pendidikan agama Islam pada sekolah adalah pegawai negeri sipil yang diangkat dalam jabatan fungsional pengawas pendidikan agama Islam yang tugas, tanggung jawab dan wewenangnya melakukan pengawasan penyelenggaraan pendidikan agama Islam pada sekolah. ${ }^{4}$

Dari beberapa pengertian diatas dapat disimpulkan bahwa yang dinamakan Pengawas Pendidikan Agama Islam (PPAI) adalah pegawai negeri sipil dari lingkungan Kementerian Agama yang diberi tugas, tanggung jawab dan wewenang penuh terhadap pelaksanaan pendidikan agama Islam di Sekolah umum dan penyelenggaraan pendidikan di Madrasah dengan melakukan penilaian dan pembinaan baik dari segi teknis pendidikan maupun administrasi pada satuan pendidikan pra sekolah, pendidikan dasar dan menengah. ${ }^{5}$

Kegiatan pengawasan pendidikan sangat diperlukan guru dalam mengembangkan profesionalisme jabatan terutama dalam pembentukan kompetensi guru. Esensi dasar dari kegiatan pengawasan diperlukan karena guru sering berhadapan dengan kondisi

${ }^{4}$ Pupuh Fathurrohman, dkk. Supervisi Pendidikan Dalam Pengembangan Proses Pengajaran (Bandung: PT Refika Aditama. 2011), h. 141-142

${ }^{5}$ Depag RI. Profesionalisme Pelaksanaan Pengawas Pendais (Jakarta: Depag RI. 2003), h. 5. 
dan situasi yang menyebabkan terhambatnya perkembangan dan pembentukan kompetensinya.

Kompetensi jabatan pengawas dipandang kebutuhan mendesak yang harus dimiliki setiap guru di Indonesia. Kondisi ini terjadi karena guru telah dipercaya oleh masyarakat luas sebagai pioneer yang berfungsi sebagai pembimbing dan pendidik siswa, sehingga menjadi manusia yang beriman, berbudi pekerti dan menguasai teknologi. Harapan yang sangat besar tersebut mewajibkan guru untuk menguasai berbagai kompetensi sehingga mengoptimalkan kinerjanya dalam mendidik siswa secara optimal.

Untuk dapat menguasai berbagai kompetensi dalam membelajarkan siswa, maka guru sangat membutuhkan layanan profesional melalui kegiatan pengawasan. Dalam konteks ini kegiatan pengawasan yang dilakukan baik oleh pengawas maupun kepala sekolah akan membentuk opini dalam diri guru tentang perlunya menguasai sejumlah kompetensi dalam aktivitas profesi.

Untuk mencapai hasil yang optimal dari kegiatan supervisi maka para pengawas dituntut untuk memiliki pemahaman tentang kepribadian guru. Hal ini mengingat bahwa guru merupakan personalia sekolah yang unik dan pengawas/kepala sekolah perlu memahami keunikan setiap guru yang dibinanya. Pidarta mengemukakan bahwa pemahaman terhadap kepribadian guru merupakan strategi bagi pengawas dalam aksinya mempengaruhi, mengarahkan, dan memotivasi para guru. Adanya pemahaman terhadap kepribadian guru merupakan hal yang sangat prinsipil, mengingat bahwa setiap guru membutuhkan teknik pembinaan tersendiri sesuai dengan karakteristik masing-masing. ${ }^{6}$

Strategi lainnya yang perlu diperhatikan pengawas dalam melaksanakan kegiatan pengawasan yaitu ketepatan dalam memilih dan dan menetapkan pendekatan dan orientasi yang digunakan. Dalam konteks ini harus dapat ditetapkan jenis pendekatan serta orientasi pengawasan yang sesuai dengan kondisi dan masalah yang dihadapi guru. Berbagai pendekatan dan orientasi pengawasan yang digunakan tersebut disesuaikan dengan jenis masalah dan karaktersitik guru yang dibina. Dengan demikian maka setiap guru akan memperoleh bimbingan/pembinaan yang berbeda sesuai dengan jenis masalah dan alternatif kemungkinan yang ditawarkan oleh kepala sekolah untuk memperbaikinya. Tingkat kemampuan kepala sekolah dalam menetapkan pendekatan serta orientasi pengawasan yang tepat sangat membantu keberhasilan pelaksanaan pengawasan dalam membina

\footnotetext{
${ }^{6}$ I Made Pidarta, Pemikiran Tentang Supervisi Pendidikan. (Jakarta: Bumi Aksara, 1992), h 37 
dan mengembangkan profesionalisme serta membentuk kompetensi dalam diri guru.

Secara implisit peranan pengawas dalam pembentukan kompetensi guru termanifestasi melalui aktivitas pengawas dalam membantu guru dalam hal peningkatan profesionalisme jabatan. Sahertian mengemukakan bahwa peranan pengawas dalam meningkatkan kompetensi guru terlihat dari usaha proaktif pengawas untuk membina dan mengembangkan potensi sumber daya guru dalam profesi mengajar terutama yang berkaitan dengan hal-hal sebagai berikut: (1) membantu guru memahami masalah-masalah umum yang di hadapi dalam tugas mengajar dan mendidik yang mencakup (a) membantu guru dalam menterjemahkan kurikulum dari pusat ke dalam bahasa belajar mengajar, (b) membantu guru-guru dalam meningkatkan program belajar mengajar yang meliputi membantu dalam merancangkan program belajar mengajar, membantu dalam merancangkan program belajar mengajar, serta membantu dalam menilai proses dan hasil belajar mengajar, (2) membantu guru memahami masalah-masalah khusus yang dihadapi guru dalam pembelajaran yang meliputi; (a) membantu guru dalam menghadapi kesulitas dalam mengajarkan tiap mata pelajaran, (b) membantu guru dalam memecahkan masalah-masalah pribadi (personal problem), (c) membantu guru dalam menghadapi masalah khusus pada setiap jenjang pendidikan. ${ }^{7}$

Evaluasi kegiatan pengawasan pada dasarnya merupakan rangkaian kegiatan yang dilakukan untuk menilai tingkat efektivitas pelaksanaan kegiatan pengawasan. Evaluasi kegiatan pengawasan ini sekaligus merupakan acuan dasar bagi pengawas untuk mengetahui tingkat kemampuan profesional yang dimilikinya dalam kegitan kepengawasan. Dalam kegiatan evaluasi pengawasan pengawas perlu melibatkan partisipasi guru sehingga secara moral guru memiliki akuntabilitas terhadap pengembangan profesionalitas jabatan guru yang diembannya.

Evaluasi kegiatan pengawasan yang dilakukan guru perlu mengacu pada beberapa aspek sebagai berikut: (a) dalam mengevaluasi penampilan guru setelah mengajar, pengawas harus berusaha agar guru memahami secara mendalam permasalahan dan titik kelemahannya, (b) pengawas perlu mengklarifikasi kembali titik kelemahan guru dalam proses belajar mengajar yang telah dilaksanakan untuk menyatukan persepsi dengan guru, (c) secara rutin pengawas mengevaluasi keseluruhan hasil pengawasan yang telah

\footnotetext{
${ }^{7}$ Piet Sahertian, Konsep Dasar Teknik Supervisi Pendidikan. (Jakarta: Rineka Cipta, 2000), h. 130-131.
} 
dilaksanakan selang waktu tertentu, (d) pengawas perlu membahas hasil temuan pengawasan secara individual yang disertai langkah proaktif untuk membina guru agar profesional dalam mengajar, (e) penilaian pengawasan harus mengacu pada alat penilaian kemampuan guru yang telah distandarkan oleh depdiknas, (f) evaluasi terhadap pengawasan dilaksanakan secara komprehensif mulai dari penyusunan program, tingkat keberhasilan pelaksanaan serta tindak lanjut pengawasan, (g) pengawas perlu menindaklanjuti hasil pengawasan dengan melakukan perbandingan antara prestasi belajar siswa sebelum guru di pengawasan dengan prestasi belajar siswa setelah guru mendapatkan pembinaan. ${ }^{8}$

Aspek yang dikemukakan di atas merupakan manifestasi dari kemampuan optimal seorang pengawas yang profesional dalam menerapkan konsep evaluasi pengawasan pendidikan. Untuk dapat mengimplementasikan kompetensi dengan maksimal dalam menjalankan tugasnya sangat dibutuhkan kesabaran dari seorang pengawas. Kesabaran ini sangat penting guna karena dengan sabar maka kesuksesan dalam melaksanakan pengawasan akan mudah diraih.

Berdasarkan uraian secara keseluruhan ini jelaslah bahwa kompetensi pengawas dalam pelaksanaan pengawasan pendidikan tergambar dalam bentuk kemampuannya untuk menjalankan kegiatan perencanaan, pelaksanaan dan evaluasi kegiatan pengawasan yang dijalankan sesuai dengan konsep dasarnya.Dengan penguasaan yang tinggi terhadap konsep dasar pengawasan pendidikan diharapkan dapat memperbaiki kinerja pengawas dalam menjalankan aktivitas kepengawasan.

Menurut Sadirman N, dkk, pengelolaan kelas adalah upaya mendayagunakan potensi kelas. Potensi yang dimaksud disini terdiri dari fasilitas yang ada pada kelas ataupun dari siswa dan gurunya dalam menyelenggarakan kegiatan di kelas. ${ }^{9}$ Seperti pendapat Haidar Nawawi (yang menjelaskan bahwa pengelolaan kelas sebagai kemampuan guru dalam mendayagunakan potensi kelas berupa pemberian kesempatan yang seluas-luasnya pada setiap personal untuk melakukan kegiatan-kegiatan yang kreatif dan terarah sehingga waktu dan dana dapat dimanfaatkan secara efesien untuk melakukan kegiatan-kegiatan kelas yang berkaitan kurikulum dan perkembangan murid. $^{10}$

\footnotetext{
${ }^{8}$ Imron, op. cit, 49.

${ }^{9}$ Sudirman,N, dkk .Ilmu pendidikan (Bandung: Remaja Rosdakarya, 1991), h. 67 .

${ }^{10}$ Haidar Nawawi, Administasi Pendidikan, (Jakarta: Haji Masagung, 1989), h. 115.

106 | Khadijah Towali
} 
Mulyasa mengemukakan bahwa pengelolaan kelas merupakan keterampilan guru untuk menciptakan iklim pembelajaran yang kondusif dan mengendalikannya jika terjadi gangguan dalam pembelajaran. ${ }^{11}$ Sedikitnya terdapat tujuh hal yang harus diperhatikan untuk menciptakan iklim pembelajaran yang kondusif dan menyenangkan yaitu ruang belajar, pengaturan sarana belajar, susunan tempat duduk, penerangan, suhu, pemanasan sebelum masuk materi yang akan dipelajari, dan bina suasana dalam belajar. ${ }^{12}$ Suharsimi Arikunto berpendapat bahwa pengelolaan kelas adalah suatu usaha yang dilakukan oleh penanggung jawab kegiatan belajar mengajar atau membantu dengan maksud agar dicapai kondisi optimal sehingga dapat terlaksana kegiatan belajar mengajar seperti yang diharapkan. ${ }^{13}$ Kegiatan pengelolaan yang dimaksud disini adalah guru dapat mendayagunakan fasilitas fisik yang ada disekitar kelas seperti jendela, meja, lampu sesuai dengan fungsi dan dibuat semenarik mungkin sehingga menjadikan kelas dengan kondisi yang nyaman dan optimal.

Menurut Mulyadi, pengelolaan kelas adalah seperangkat kegaitan untuk mengembangkan tingkah laku siswa yang diinginkan dan mengurangi atau meniadakan tingkah laku yang tidak diinginkan, mengembangkan hubungan interpersonal dan iklim sosio emosional yang positif serta mengembangkan dan mempertahankan organisasi kelas yang efektif dan produktif. ${ }^{14}$ Dari pemaparan menurut ahli di atas dapat ditarik benang merah bahwa pengelolaan kelas adalah suatu kegiatan yang terdiri dari mengatur, mengurus dan menyelenggarakan kegiatan kelas dengan mendayagunakan fasilitas seperti memanfaatkan meja dengan posisi tertentu, membuka jendela supaya udara segar dapat masuk ke ruangan, dan lain sebagainya. Selain itu pengelolaan kelas dapat menjadi wadah untuk mendekatkan murid dan guru dengan itu dapat membantu merubah sikap siswa yang tidak baik dalam kelas menjadi baik dan menaati peraturan. Hal ini bertujuan supaya menciptakan iklim harmonis di dalam kelas sehingga tercapainya tujuan pembelajaran yang diinginkan.

Berdasarkan beberapa defenisi di atas, maka dapat disimpulkan bahwa pengelolaan kelas adalah keterampilan guru untuk menciptakan

\footnotetext{
${ }^{11}$ E. Mulyasa, Menjadi Guru Profesioanal, (Bandung: Remaja Rosda Karya, 2007), h. 91

${ }^{12}$ Abdul Majid, Perencanaan Pembelajaran, (Bandung,: PT Remaja Rosda Karya, 2012), h. 165

${ }^{13}$ Arikunto Suharsim, Pengelolan Kelas dan Siswa. (Jakarta, Rajawali, 1988). h. 67.

${ }^{14}$ Mulyadi, Classroom Management, (Malang: UIN-Malang Press, 2009) h. 
suasana belajar yang kondusif sehingga siswa dapat mengikuti pembelajaran dengan tenang. Guru juga harus dapat mengendalikan kelas apabila terjadi gangguan-gangguan yang dapat mengganggu ketenangan siswa dalam mengikuti pembelajaran.

\section{Strategi Pengawas Guru PAI Dalam Meningkatkan Pengelolaan Kelas}

Kelas sebagai lingkungan belajar siswa merupakan aspek dari lingkungan yang harus diorganisasikan dan dikelola secara sistematis. Lingkungan ini harus diawasi agar kegiatan belajar mengajar bisa terarah dan menuju pada sasaran yang dikehendaki. Adapun karakteristik lingkungan yang baik itu diantaranya adalah kelas memiliki sifat merangsang dan menantang siswa untuk selalu belajar, memberikan rasa aman dan kepuasan dalam mencapai tujuan belajar. Yang lain bisa dipandang sebagai indikasi keberhasilan pengelolaan kelas. Dari sini, terasa tepat bila dikatakan, bahwa pengelolaan kelas secara dinamis merupakan penentu perwujudan proses belajar mengajar yang efektif.

Komponen penting lainnya yang perlu dideskripsikan adalah menyangkut keadaan siswa. Hal tersebut dipandang urgen, mengingat siswa merupakan, mengingat siswa merupakan subyek belajar yang diharapkan ke depan menjadi generasi yang dapat mengemban amanat zaman yang handal dan kompoten dalam berbagai bidang, sehingga mampu menatap hari depan dengan percaya diri. Hal tersebut dipandang urgen, mengingat siswa merupakan subyek belajar yang diharapkan ke depan menjadi generasi yang dapat mengemban amanat zaman yang handal dan kompoten dalam berbagai bidang. Adapun keadaan siswa Sekolah Dasar yang menjadi tempat penelitian adalah sebagaiman yang terlihat pada table dibawah ini:

\begin{tabular}{ccc}
\multicolumn{2}{c}{ Keadaan } & Siswa Sekolah Dasar se Kecamatan Marisa \\
No & Nama Sekolah & Jumlah Siswa \\
\hline 1 & SDN 01 Marisa & 405 Orang \\
\hline 2 & SDN 02 Marisa & 228 Orang \\
\hline 3 & SDN 03 Marisa & 192 Orang \\
\hline 4 & SDN 04 Marisa & 172 Orang \\
\hline 5 & SDN 06 Marisa & 407 Orang \\
\hline 6 & SDN 07 Marisa & 376 Orang \\
\hline 7 & SDN 08 Marisa & 176 Orang \\
\hline 8 & SDN 09 Marisa & 104 Orang
\end{tabular}

Sumber Data: Dinas Pendidikan Kabupaten Pohuwato 2019 


\section{Langkah-langkah Pengawas Guru PAI dalam Meningkatkan Tata Kelola Kelas Sekolah Dasar se-Kecamatan Marisa}

Ada anggapan bahwa Pendidikan Agama Islam (PAI) yang selama ini berlangsung agaknya kurang concern terhadap persoalan bagaimana mengubah pengetahuan agama yang bersifat kognitif menjadi makna dan nilai yang perlu diinternalisasikan dalamdiri siswa. Sebab itu, Pendidikan Agama Islam dianggap gagal dalam pembentukan pribadi siswa yang baik. Dalam kondisi yang demikian, guru tidak hanya bertugas sebagai fasilitator, tetapi sekaligus harus menjadi motivator bagi siswa dalam rangka mengembangkan kemampuan belajar anak, mengembangkan kondisi belajar yang relevan agar tercipta suasana belajar Pendidikan Agama Islam yang lebih menarik. Oleh karena itu, agar pendidikan dan pengajaran yang dipaparkan oleh guru kepada anak didik dapat memberi keseimbangan antara ranah kognitif, afektif, dan psikomotorik, maka guru dituntut agar dapat memformat metode pengajaran semenarik mungkin. Karena metode yang digunakan di sekolah dirasakan masih kurang menciptakan suasana kondusif dan menyenangkan bagi siswa untuk dapat mempelajari Pendidikan Agama Islam. Metode yang digunakan tidak boleh monoton, hanya terfokus pada buku pelajaran dan ceramah dari guru. Tetapi lebih dari itu, proses belajar harus mampu menjadikan siswa mampu membiasakan diri lebih kreatif.

Dalam rangka meningkatkan kualitas Pendidikan Agama Islam, maka Supervisor SDN Se-Kecamatan Marisa melakukan supervisi bagi guru untuk membantu mereka dalam mengembangkan tugas tata kelola kelas sebagai guru, sehingga proses belajar mengajar lebih berkualitas dan nyaman. sebagaimana wawancara dengan salah seorang kepala sekolah di SDN Kecamatan Marisa menyatakan bahwa:

Profesi guru dalam mengembangkan kegiatan belajar mengajar akan selalu dan terus berjalan seiring dengan perkembangan ilmu pengetahuan dan teknologi. Tentunya kondisi ini berpengaruh terhadap dunia pendidikan. Sebab itu, bantuan supervisi kepala sekolah maupun supervisi pengawas sangat penting dalam rangka mengembangkan profesional guru sehingga dapat melaksanakan tugasnya dengan maksimal. Dengan adanya pengawasan tersebut dapat memberikan dampak positif dalam menumbuhkan dan mengembangkan profesi guru, baik secara langsung maupun tidak langsung. Supervisi inilah yang juga dilakukan bagi guru Pendidikan Agama Islam SDN Se-kecamatan Marisa ini. Kita harus mengakui, bahwa meskipun guru-guru Pendidikan Agama Islam di sini seluruhnya tamatan sarjana $\mathrm{S} 1$, tetapi dalam menjalankan tugasnya masih membutuhkan pengarahan dan pembinaan dari kepala maupun 
supervisor atau pengawas. Dalam meningkatkan tata kelola kelas guru PAI terus kita dorong, baik secara individual melalui penataran, melalui pelatihan dan supervisi. dan dilaksanakan perencanaannya tiap awal sementer. ${ }^{15}$

Dari informasi yang disampaikan di atas, dapat dipahami bahwa pelaksanaan supervisi Pendidikan Agama Islam di SDN Sekecamatan Marisa direncanakan setiap awal semester. Pada dasarnya perencanaan adalah proses penentuan tujuan atau sasaran yang hendak dicapai dan menetapkan jalan dan sumber yang diperlukan untuk mencapai tujuan yang dimaksud seefisien dan seefektif mungkin. Hasil penelitian mengungkap bahwa supervisi atau pengawasan SDN Se-kecamatan Marisa dilakukan sesuai dengan rencana yang telah ditetapkan.

Hal ini juga dikuatkan oleh pengawas Pendidikan Agama Islam (PAI) ketika wawancara sebagai berikut:

"Selama menjadi pengawas PAI di Kabupaten Pohuwato dan Kecamatan Marisa adalah merupakan wilayah sudah saya melakukan pengawasan berjalan selama 2 tahun. Supervisi PAI yang berlangsung di SDN Kecamatan Marisa Khususnya dibagi kepada dua. Ada yang tidak direncanakan atau dilakukan secara tiba-tiba dan ada yang direncanakan. Supervisi yang direncanakan dilakukan dengan cara terlebih dahulu disiapkan kepala sekolah jadwal guru yang akan disupervisi, kemudian pengawas bersama kepala sekolah melaksanakan supervisi terhadap guru, sesuai dengan jadwal yang sudah ditentukan. Supervisi yang direncanakan bertujuan untuk membantu guru mengembangkan kemampuan mengelola proses pembelajaran, sehingga tercapai tujuan pembelajaran. Perencanaan supervisi pada awalnya dilakukan di kantor Dinas Pendidikan Popayato dan Kementrian Agama Popayato dengan seluruh kelompok kerja pengawas (Pokjawas), kemudian hasil musyawarah itulah yang akan disampaikan kepada setiap sekolah dan sekolah kembali memusyawarhkan hari pelaksanaan supervisi. Program supervisi yang telah direncanakan biasanya dilaksanakan pada awal semester. Tujuannya adalah agar tersosialisasi dengan baik program pengawasan sebagaimana yang diinginkan". ${ }^{16}$

Berdasarkan uraian di atas, dapat dipahami bahwa perencanaan supervisi oleh pengawas Kecamatan Marisa adalah untuk meningkatkan mutu proses dan mutu hasil pembelajaran. Dari

\footnotetext{
${ }^{15}$ Lilis Napu, Kepala Sekolah SDN 06 Marisa, Wawancara, Tanggal 28 Juli 2019

${ }^{16}$ Pahudin, S.Pd.I, Pengawas Guru PAI Dinas Pendidikan Kabupaten Popayato, Wawancara Tanggal 05 Agustus 2019.
} 
informasi di atas juga dipahami bahwa sasaran utama dari supervisi yang dilakukan oleh pengawas adalah supervisi akademik. Sasaran utama supervisi akademik adalah kemampuan-kemampuan guru dalam merencanakan kegiatan pembelajaran, melaksanakan kegiatan pembelajaran, menilai hasil pembelajaran, memanfaatkan hasil penilaian untuk peningkatan layanan pembelajaran, menciptakan lingkungan belajar yang menyenangkan, memanfaatkan sumber belajar yang tersedia, dan mengembangkan interaksi pembelajaran (strategi, metode, teknik) yang tepat.

Hal ini erat kaitannya dengan informasi yang disampaikan oleh Pengawas PAI dengan petikan wawancara sebagai berikut :

"Saya sebagai seorang supervisor Pendidikan Agama Islam di SDN Se-Kecamatan Marisa, melakukan supervisi yang meliputi beberapa aspek, yaitu perencanaan pembelajaran, apakah ada direncanakan atau tidak pembelajaran PAI di sekolah tersebut. Kemudian, supervisi yang berhubungan dengan administrasi guru yang meliputi program semester, silabus, RPP, jadwal tatap muka, agenda harian, daftar nilai, dan absensi siswa. Pada komponen pelaksanaan pembelajaran, kegiatan supervisi diarahkan pada kemampuan guru dalam mengelola kelas, dimulai dari kegiatan pendahuluan, kegiatan inti, dan penutup. Sedangkan pada kegiatan tindak lanjut, kegiatan supervisi diarahkan pada pembimbingan dan pelatihan profesional guru, dan dilakukan upaya perbaikan mutu pendidikan melalui supervisi administrasi penilaian pembelajaran dengan jalan pembimbingan guru sebagai refleksi dan feedback hasil penilaian kinerja." ${ }^{\prime 17}$

Selanjutnya Pahudin menjelaskan dari hasil temuan penelitian menurut penuturan pengawas PAI bahwa:

"Strategi kepengawasan yang dilakukan oleh semua pengawas adalah merencanakan dan menyiapkan perangkat kepengawasannya sebelum melakukan supervisi. Perangkat kepengawasan tersebut terhimpun dalam program tahunan, semester dan bulanan. Pada tiap awal tahun ajaran semua pengawas melalui Kelompok Jajaran Pengawas (Pokjawas) sudah mempersiapkan dan menyusun program dimaksud sedemikian rupa sehingga pada saat pelaksanaan supervisi mereka menggunakan program yang sama. Hanya dalam program tersebut belum tercermin secara jelas bagaimana kiat-

\footnotetext{
${ }^{17}$ Raina Sune, Pahudin, S.Pd.I, Pengawas Guru PAI Kabupaten Popayato, Wawancara Tanggal 05 Agustus 2019.
} 
kiat atau upaya yang dapat dianggap sebagai langkah strategis untuk meningkatkan profesionalitas guru."

Berdasarkan informasi yang disampaikan pengawas PAI Kecamatan Marisa, dapat dipahami bahwa aspek-aspek yang di supervisi oleh pengawas PAI adalah aspek perencanaan, pelaksanaan kegiatan belajar mengajar, dan kegiatan tindak lanjut. Dalam menyusun perencanaan pengawasan, seperti yang diungkapkan di atas, dapat dipahami yang menjadi dasar perencanaan adalah pertama, dengan cara melihat kemampuan guru, kira-kira apa yang menjadi kekurangan dan kelebihanguru dan yang kedua adalah dengan cara melihat latar belakang guru. Penyusunan program pengawas yang dilaksanakan pengawas PAI di SDN se-Kecamatan Marisa merupakan suatu kebutuhan. Hasil penelitian menunjukkan bahwa pengawas PAI telah membuat perencanaan program pengawasan. Hal ini dapat ditegaskan, bahwa tanpa perencanaan tersebut, maka kegiatan supervisi yang dilakukan oleh pengawas tidak akan dapat berjalan degan lancar. Perencanaan dapat diartikan sebagai proses penyusunan berbagai keputusan yang akan dilaksanakan pada masa yang akan datang untuk mencapai tujuan yang telah ditentukan. Perencanaan yang dilakukan meliputi supervisi KBM dan perencanaan pengawasan yang dilakukan pada akhir semester.

Menurut Pengawas PAI bahwa:

"Program tahunan, semester maupun bulanan atau bahkan mingguan, merupakan tugas rutin Pengawas yang harus dibuat pada setiap awal tahun ajaran sebelum melaksanakan supervisi. Karena program tersebut merupakan rujukan setiap pengawas dalam melaksanakan tugasnya, terlebih lagi dalam menyusun langkah-langkah strategis kepengawasan guna meningkatkan profesionalitas guru di sekolah. Melalui program tersebut sudah tercermin bagaimana model pendekatan yang akan dilakukan oleh pengawas. Oleh karena itu,melalui Pokjawas para pengawas harus benar-benar membuat sebuah perencanaan yang matang dan bersifat dinamis. Artinya dalam perencanaan tersebut berisi tentang model pendekatan yang selama ini digunakan,agar guru benar-benar merasakan sesuatu yang dinamis dalam pembinaan." 19

Selanjutnya, penulis juga menanyakan kepada pengawas tentang rencana pelaksanaan supervisi di SDN se- Kecamatan Marisa.

\footnotetext{
${ }^{18}$ Pahudin, S.Pd.I, Pengawas Guru PAI Dinas Pendidikan Kabupaten Popayato, Wawancara Tanggal 25 Agustus 2019.

${ }^{19}$ Yusra Tilameo, Pengawas Guru PAI Kabupaten Popayato, Wawancara Tanggal 25 Agustus 2019

112 | Khadijah Towali
} 
Dari wawancara yang berlangsung, diperoleh informasi bahwa supervisi Pendidikan Agama Islam dilaksanakan dengan terlebih dahulu bermusyawarah dengan pihak sekolah. Dalam pelaksanaan supervisi, saya terlebih dahulu mengawalinya dengan melakukan pertemuan awal dengan kepala madrasah dan guru-guru serta staf administrasi madrasah, sebab dengan pertemuan itu saya dengan kepala madrasah, guru-guru dan staf administrasi melakukan kata sepakat untuk bekerja sama melaksanakan supervisi. Selain itu, karena tiap sekolah itu ada kepala sekolah yang menjadi pimpinan disitu, saya harus minta izin terlebih dahulu kepadanya, baru saya laksanakan tugas saya sebagai pengawas. Diawal pertemuan itulah dijadwalkan rencana-rencana pelaksanaan supervisi di sekolah tersebut, sehingga dapat dipahami secara bersama-sama. ${ }^{20}$

Di samping itu dalam membuat perencanaan kerja di bidang supervisi pendidikan, ada beberapa langkah yang harus diperhatikan antara lain: (1) Melakukan identifikasi masalah; (2) Mengolah dan menganalisis hasil identifikasi masalah; (3) Merumuskan perencanaan kerja pengawas; dan (4) Menilai efektivitas pelaksanaan program kegiatan supervisi berdasarkan tujuan-tujuan yang telah ditetapkan. ${ }^{21}$

Informasi yang dikemukakan pengawas juga mengindikasikan bahwa perencanaan supervisi PAI di SDN Se-Kecamatan Marisa, melibatkan beberapa unsur, yaitu pengawas, kepala sekolah dan guru. Secara realitas harus disadari, bahwa berjalan dan berkembangnya sebuah kegiatan pada lembaga pendidikan, seperti halnya pelaksanaan supervisi PAI di SDN Se-Kecamatan Marisa tidak lepas dari berbagai unsur yang berperan. Unsur yang dimakud adalah komponenkomponen yang terkait dengan pelaksanaan supervisi. Peran dan eksisnya supervisi dapat membantu bagi peningkatan kualitas pembelajaran di sebuah sekolah. Dari hasil analisis dan identifikasi yang dilakukan dalam hal ini, dikuatkan oleh informasi dari kepala madrasah pada saat diwawancarai sebagai berikut.

"Dalam rangka menyukseskan kegiatan supervisi akademik dalam bidang Pendidikan Agama Islam, beberapa hal yang dipersiapkan yaitu memeriksa kesiapan perangkat pembelajaran, mengamati proses pembelajaran dan melakukan refleksi. Tetapi sebelum itu dilakukan, bentuk-bentuk supervisi yang dilakukan adalah meliputi kegiatan belajar mengajar siswa, kegiatan yang

\footnotetext{
${ }^{20}$ Pahudin, Pengawas Guru PAI Dinas Pendidikan Kabupaten Popayato, Wawancara Tanggal 25 Agustus 2019

${ }^{21}$ Departemen Agama RI, Pedoman Pengembangan Administrasi dan Supervisi Pendidikan, (Jakarta:Dirjen Kelembagaan Agama Islam, 2003),.h.52
} 
dilakukan siswa dan proses pembelajaran yang sedang berlangsung". ${ }^{22}$

Dari uraian di atas, dapat dipahami bahwa supervisor menjalankan tugas kepengawasannya dengan baik. Supervisor memiliki kompetensi dalam menjalankan tugas dan tanggung jawabnya sebagai pengawas. Dalam kaitan itu, supervisor PAI juga melakukan langkah-langkah supervisi dengan berbagai cara. Menurutpenjelasan kepala madrasah, ada tiga langkah yang digunakan dalam pelaksanaan supervisi oleh pengawas Pendidikan Agama Islam. Langkah tersebut mengacu kepada panduan tugas pengawas Pendidikan Agama Islam, yaitu melakukan persiapan, pelaksanaan supervisi dan penilaian supervisi.

Dalam kesempatan wawancara dijelaskan Pengawas sebagai berikut:

"Untuk mendukung kelancaran rencana supervisi yang telah ditetapkan ada tiga langkah yang dilakukan supervisi, yaitu menyiapkan format supervisi, kemudian melaksanakan supervisi dengan melakukan pengamatan terhadap kegiatan belajar mengajar dan melakukan penilaian dan evaluasi, salah satu bentuk strategi kepengawasan yang dilakukan pengawas adalah membuat dan menggunakan instrumen yang sama, yakni instrumen yang sudah disepakati oleh Pokjawas Kantor Kementerian Agama Provinsi Gorontalo. Menurut beberapa Pengawas, instrumen tersebut bisa saja berubah sesuai dengan kondisi pada saat itu dan dengan tujuan supervisi yang akan dilakukan dan berdasarkan kesepakatan Pokjawas. Namun,selama ini Pengawas belum mengembangkan instrumennya kearah yang lebih spesifik untuk mengetahui potensi yang dimiliki guru PAI ke arah pengembangan yang lebih professional". 23

Dari informasi di atas, dapat dipahami bahwa ketiga proses atau langkah di atas menjadi acuan bagi pelaksanaan supervisi Pendidikan Agama Islam di SDN se-Kecamatan Marisa. Ketika peneliti mewawancarai seorang guru Pendidikan Agama Islam Ibu Lis Oka, diperoleh informasi bahwa ia disupervisi oleh pengawas PAI sekali dalam setiap semester, sesuai dengan jadwal yang telahditentukan. Supervisi tersebut meliputi supervisi terhadap kegiatan belajar mengajar yang dilakukan dengan cara kunjungan

\footnotetext{
${ }^{22}$ Rita K. Husain, Kepala Sekolah SDN 04 Marisa, Wawancara Tanggal 29 Agustus 2019

${ }^{23}$ Raina Sune, S.Pd.I, Pengawas Guru PAI Kabupaten Popayato, Wawancara Tanggal 25 Agustus 2019

114 | Khadijah Towali
} 
kelas dan mengadakan bimbingan setelah supervisi. Guru mata pelajaran PAI Menjelaskan menjelaskan sebagai berikut:

"Menurut saya, pelaksanaan supervisi Pendidikan Agama Islam di SDN se-Kecamatan Marisa sudah baik. Jadwal pelaksanaan supervisi sesuai dengan yang direncanakan, minimal sekali dalam satu semester. Supervisi yang dilakukan meliputi kegiatan belajar mengajar, kemudian setelah itu ada penilaian, sehingga diketahui kekurangan yang harus diperbaiki seorang guru. Setelah dilakukan supervisi, ada juga diadakan bimbingan sesuai dengan kurikulum". ${ }^{24}$

Berdasarkan uraian di atas, dapat dipahami bahwa rencana pelaksanaan supervisi Pendidikan Agama Islam di SDN se-Kecamatan Marisa, telah dilakukan dari awal semester dengan terlebih dahulu memusyawarahkannya. Rencana tersebut kemudian disusun dalam program supervisi. Program disusun sebagai acuan untuk melaksanakan supervisi. Penyusunan program yang dimaksud adalahpembuatan jadwal kunjungan dan pembuatan penyiapan instrumen. Sebagaimana informasi yang diperoleh penulis dari pengawas Pendidikan Agama Islam.

\section{Faktor Pelaksanaan Pengawas Guru PAI dalam Meningkatkan} Profesionalitas Guru Sekolah Dasar se-Kecamatan Marisa

Supervisi akademik merupakan salah satu hal yang sangat penting untuk meningkatkan kemampuan profesional guru dan kualitas pembelajaran. Proses pembelajaran yang baik dapat menciptakan lulusan yang baik dari segi kualitas maupun kuantitas. Oleh karena itu,kegiatan supervisi dituntut untuk dilakukan secara rutin di sekolah sebagai salah satu kegiatan yang dipandang positif dalam meningkatkan kualitas pembelajaran. Apabila konsep-konsep ideal supervisi dilaksanakan, maka dapat diharapkan kualitas pendidikan akan meningkat secara signifikan.Supervisi akademik sebaiknya dilakukan dengan pendekatan supervisi klinis yang dilaksanakan secara berkesinambungan melalui tahapan pra-observasi, observasi pembelajaran, dan pasca observasi. Idealita supervisi akademik tersebut, praktiknya di lapangan selama ini masih jauh dari harapan. Berbagai kendala baik yang disebabkan oleh aspek struktur birokrasi yang rancu, maupun kultur kerja dan interaksi supervisor dengan guru yang kurang mendukung, telah mendistorsi nilai ideal supervisi di sekolah-sekolah.

\footnotetext{
${ }^{24}$ Lis Oka Guru PAI SDN O6 Marisa Kabupaten Popayato, Wawancara Tanggal 29 Agustus 2019
} 
Sebagaimana dipahami bahwa supervisi akademik adalah serangkaian kegiatan membantu guru mengembangkan kemampuannya mengelola proses pembelajaran demi pencapaian tujuan pembelajaran. Fungsinya adalah sebagai penilaian kinerja guru dalam mengelola proses belajar mengajar sesuai dengan kemampuannya. Supervisi akademik juga merupakan refleksi praktis untuk melihat realitas dalam pengelolaan kegiatan belajar mengajar, mulai dari perencanaan penyajian materi, penilaian dan perbaikan dari hasil proses belajar mengajar. Supervisi juga berfungsi untuk melihat kelebihan dan kekurangan guru dan upaya untuk mengembangkan kemampuan guru dalam rangka memfasilitasi belajar bagi murid, agar kualitas hasil belajar optimal. Maka hakikat supervisi akademik adalah membantu guru untuk mengembangkan kemampuan profesionalnya.

Supervisi akademik merupakan tanggung jawab bersama antara supervisor dengan guru. Dalam kaitan ini, maka pelaksanaan supervisi pengawas PAI dengan kepala madrasah pada kegiatan belajar mengajar di SDN se-Kecamatan Marisa mencakup tiga tahapan, yaitu tahap persiapan, tahap pelaksanaan dan tahap penilaian dan tindak lanjut. Hal ini diketahui dari hasi wawancara yang dilakukan dengan Pengawas yang dijelaskannya sebagai berikut:

"Untuk mencapai kelancaran supervisi Pendidikan Agama Islam (PAI) di SDN se-Kecamatan Marisa, kita sebagai pengawas, melakukan kerjasama dengan sekolah. Kita membicarakan bersama-sama solusi yang paling tepat untuk dilakukan dalam meningkatkan pengelolaan kelas. Kemudian kita melakukan pengamatan, mempersiapkan segala sesuatu yang berkaitan dengan perangkat pembelajaran, kita siapkan instrumen penilaiannya dan kemudian kita melakukan kunjungan kelas. Setelah melakukan kunjungan kelas, kemudian diadakan refleksi, dan pembinaan guru". ${ }^{25}$

Selanjuntanya menurut pengawas bahwa:

"Setelah melakukan kerjasama selanjutnya kami sebagai pengawas melakukan kunjungan ke sekolah dan observasi kelas merupakan kegiatan inti bagi seorang supervisor. Oleh karena itu, bentuk kegiatan ini tidak bisa diabaikan kami abaikan sebagai supervisor, sebab dari sinilah kami tahu mengetahui kemampuan guru dalam mengelola pembelajaran untuk selanjutnya mengatur

\footnotetext{
${ }^{25}$ Pahudin, Pengawas Guru PAI Kabupaten Popayato, Wawancara Tanggal 29 Agustus 2019

116 | Khadijah Towali
} 
strategi kepengawasan dalam rangka meningkatkan profesionalitas guru". ${ }^{26}$

Keberhasilan kegiatan supervisi pada suatu sekolah tidak terlepas dari peran dan tanggung jawab supervisor, karena supervisor dianggap sebagai penanggungjawab terhadap proses pembelajaran di sekolahnya. Supervisor hendaknya mampu memahami dan mengetahui bagaimana kemampuan gurunya melakukan proses pembelajaran. Disamping itu,ia juga harus mampu memberikan pengertian yang cukup kepada gurunya tentang kegunaan dan manfaat supervisi.

Dalam pelaksanaan Supervisi sebagaimana wawancara berikut ini:

"Dalam melaksanakan supervisi PAI, kita tidak lagi memberitahukan kepada guru bersangkutan, sebab kita sudah menyepakati secara bersama-sama, bahwa supervisi dilakukan pada saat guru bersangkutan mengajar. Ini dilakukan, supaya guru yang bersangkutan mempersiapkan seluruh perangkat yang akan disupervisi dan di bawanya langsung pada saat mengajar. Jadi lebih praktis. Kadang-kadang, kita tidak bertemu dengan guru yang akan disupervisi. Kita hanya meminta kepada guru bersangkutan untuk mengumpulkan perangkat yang terkait dengan bahan-bahan yang akan disupervisi, dan menyerahkannya kepada kepala sekolah. Kemudian kepala sekolah memberikan kepada pengawas untuk diperiksa atau dinilai". ${ }^{27}$

Untuk mendapatkan hasil yang maksimal dalam supervisi, diperlukan suatu pendekatan yang tepat. Pendekatan dalam supervisi disebut teknik, baik yang bersifat individual maupun kelompok yang masing-masing memiliki kelebihan dan kekurangan. Teknik yang digunakan dalam supervisi merupakan sebuah strategi kepengawasan yang harus dikembangkan untuk menjadikan guru lebih profesional di bidangnya. Untuk meningkatkan profesional guru,seorang supervisor tidak hanya menggunakan satu teknik supervisi, akan tetapi harus dicoba dengan teknik lain untuk menyesuaikan dengan keadaan dan tujuan yang ingin dicapai. Menurut Sahertian, teknik yang bersifat individual adalah teknik yang dilaksanakan untukseorang guru secara individual, teknik seperti ini dilakukan berupa kunjungan kelas atau observasi kelas, percakapan pribadi, intervisitasi, menyeleksi berbagai sumber materi untuk mengajar dan menilai diri sendiri. Sedangkan yang bersifat kelompok adalah teknik yang dilakukan untukmelayani

\footnotetext{
${ }^{26}$ Pahudin, Pengawas Guru PAI Kabupaten Popayato, Wawancara Tanggal 25 Agustus 2019.

${ }^{27}$ Yusra Tilameo, Pengawas Guru PAI Kabupaten Popayato, Wawancara Tanggal 01 September 2019.
} 
lebih dari satu orang,misalnya pertemuan oreintasi bagi guru baru, panitia penyelenggara, rapat guru, studi kelompok antar guru, diskusi kelompok, tukar menukar pengalaman (sharing of experience), lokakarya (workshop), diskusi panel, seminar, simposium, demonstrasi mengajar, dan sebagainya. ${ }^{28}$

Pengawas SDN se-Kecamatan Marisa melakukan dengan dua cara, yaitu melalui kepala sekolah dan langsung oleh pengawas PAI. Melalui kepala sekolah, dalam hal ini pengawas menyampaikan catatan-catatan penilaian kepada kepala sekolah terkait dengan guru yang disupervisi. Kepala sekolah diminta untuk menyampaikan penilaian kepada guru yang bersangkutan. Sedangkan yang dilakukan melalui pengawas PAI, dalam hal ini pengawas PAI menyampaikan langsung kepada guru yang bersangkutan. Setelah dilakukan penilaian, maka tahap selanjutnya adalah melakukan pembinaan, dan merancang program peningkatan kualitas guru. Program seperti ini dilakukan secara berkesinambungan oleh pengawas PAI SDN seKecamatan Marisa

Menurut Pahudin demi memaksimalkan kinerja pengawas biasanya setelah kami sebagai pengawas melakukan supervisi dalam bentuk kunjungan kelas selalu diikuti oleh tindak lanjut. Tindak lanjut yang dilakukan biasanya dengan melakukan diskusi atau berbincangbincang dengan guru disebuah ruangan membicarakan hasil supervisi, selanjutnya dilaporkan kepada Kepala Sekolah setelah guru memberikan tanda tangan. Beberapa guru memberikan pernyataan, bahwa materi diskusi bersifat biasa-biasa saja, tidak ada langkah yang sifatnya terobosan yang diagendakan untuk dilakukan kedepannya. Padahal kesempatan seperti ini merupakan saat yang tepat bersamabersama guru untuk mengatur strategi apa yang akan diterapkan dalam rangka meningkatkan profesionalitas guru. ${ }^{29}$

Berdasarkan hasi wawancara dengan supervisi SDN seKecamatan Marisa diperoleh informasi bahwa dalam melakukan supervisi PAI, pengawas melakukan supervisi dengan melakukan kunjungan kelas. Kunjungan kelas adalah teknik pembinaan yang dilakukan pengawas dalam rangka mengamati pelaksanaan proses belajar mengajar, sehingga memperoleh data yang diperlukan dalam rangka pembinaan guru. Tujuan kunjungan kelas ini adalah untuk menolong guru dalam mengatasi kesulitan atau masalah guru di dalam kelas. Melalui kunjungan kelas, pengawas akan membantu

\footnotetext{
${ }^{28}$ Sahertian, Piet A., Konsep Dasar dan Teknik Supervisi Pendidikandalam Rangka Pengembangan Sumber Daya Manusia, (Jakarta: Rineka Cipta, 2000), h. 52

${ }^{29}$ Pahudin, Pengawas Guru PAI Kabupaten Popayato, Wawancara Tanggal 01 September 2019
} 
permasalahan yang dialaminya.Kunjungan kelas ini tidak lagi diberitahukan kepada guru yang bersangkutan, karena jadwalnya sudah disesuaikan dengan jadwal masing-masing guru pada saat mengajar.

\section{Kesimpulan}

Strategi kepengawasan yang dilakukan oleh semua pengawas adalah merencanakan dan menyiapkan perangkat kepengawasannya sebelum melakukan supervisi.Perangkat kepengawasan tersebut terhimpun dalam program tahunan, semester dan bulanan. Pada tiap awal tahun ajaran semua pengawas melalui Kelompok Jajaran Pengawas (Pokjawas) sudah mempersiapkan dan menyusun program dimaksud sedemikian rupa sehingga pada saat pelaksanaan supervisi mereka menggunakan program yang sama. Hanya dalam program tersebut belum tercermin secara jelas bagaimana kiat-kiat atau upaya yang dapat dianggap sebagai langkah strategis untuk meningkatkan profesionalitas guru.

Dalam melaksanakan supervisi PAI, kita tidak lagi memberitahukan kepada guru bersangkutan, sebab kita sudah menyepakati secara bersama-sama, bahwa supervisi dilakukan pada saat guru bersangkutan mengajar. Ini dilakukan, supaya guru yang bersangkutan mempersiapkan seluruh perangkat yang akan disupervisi dan di bawanya langsung pada saat mengajar. Jadi lebih praktis. Kadang-kadang, kita tidak bertemu dengan guru yang akan disupervisi. Kita hanya meminta kepada guru bersangkutan untuk mengumpulkan perangkat yang terkait dengan bahan-bahan yang akan disupervisi, dan menyerahkannya kepada kepala sekolah. Kemudian kepala sekolah memberikan kepada pengawas untuk diperiksa atau dinilai.

\section{Daftar Pustaka}

Departemen Agama RI. Profesionalisme Pelaksanaan Pengawas Pendais, Jakarta: Depag RI. 2003.

Departemen Agama RI. Profesionalisme Pelaksanaan PengawasPendidikan, (Upaya Meningkatkan Kinerja Pengawas), Jakarta: Direktorat Jendral Kelembagaan Agama Islam, 2005.

Departemen Agama RI, Pedoman Pengembangan Administrasi dan Supervisi Pendidikan, Jakarta:Dirjen Kelembagaan Agama Islam, 2003. 
Djamarah, Syaiful Bahri dan Aswan Zain, Strategi Belajar Mengajar. Jakarta: Rineka Cipta, 2002.

E. Mulyasa, Menjadi Guru Profesioanal, Bandung: Remaja Rosda Karya, 2007.

Fathurrohman, Pupuh, dkk. Supervisi Pendidikan Dalam Pengembangan Proses Pengajaran, Bandung: PT Refika Aditama. 2011.

Harsanto, Radno. Pengelolaan Kelas yang Dinamis. Yogyakarta: Kanisius, 2007.

Husain, Rita K., Kepala Sekolah SDN 04 Marisa, Wawancara Tanggal 29 Agustus 2019

Majid, Abdul, Perencanaan Pembelajaran, Bandung,: PT Remaja Rosda Karya; 2012.

Mulyadi, Classroom Management, Malang: UIN-Malang Press, 2009.

Napu, Lilis, Kepala Sekolah SDN 06 Marisa, Wawancara, Tanggal 28 Juli 2019

Nawawi, Haidar, Administasi Pendidikan. Jakarta: Haji Masagung, 1989.

Oka, Lis Guru PAI SDN O6 Marisa Kabupaten Popayato, Wawancara Tanggal 29 Agustus 2019

Pahudin, Pengawas Guru PAI Dinas Pendidikan Kabupaten Popayato, Wawancara Tanggal 05 Agustus 2019

Pidarta, I Made. 1992. Pemikiran Tentang Supervisi Pendidikan. Jakarta : Bumi Aksara

Rohani, Rohani. 2004. Pengelolaan Pengajaran. Jakarta. Rineka Cipta

Sahertian, Piet. A. Konsep Dasar dan Teknik SupervisiPendidikan Dalam Rangka Pengembangan Sumber Daya Manusia, Jakarta: Rineka Cipta, 2000.

Sopiatin, Popi. Manajemen Belajar Berbasis Kepuasan Siswa,Bogor: Ghalia Indonesia, 2010.

Sudirman, N, dkk .Ilmu pendidikan, Bandung: Remaja Rosdakarya: 1991.

Suharsim, Arikunto, Pengelolan Kelas dan Siswa. Jakarta, Rajawali, 1988.

Sumadi Suryabrata, Metodologi Penelitian. 1993. Jakarta :Raja Grafindo Persada

Sune, Raina, Pengawas Guru PAI Kabupaten Popayato, Wawancara Tanggal 05 Agustus 2019

Tilameo, Yusra, Pengawas Guru PAI Kabupaten Popayato, Wawancara Tanggal 25 Agustus 2019 